\title{
Bacteriological quality assessment of a subtropical temple pond of Birpur, Jammu (J\&K, India)
}

\author{
${ }^{1}$ K.K. Sharma, ${ }^{1}$ Neha Antal $*,{ }^{2}$ Sanjana Kaul, ${ }^{1}$ Aarti Devi, ${ }^{1}$ Sarbjeet Kour and \\ ${ }^{1}$ Arti Sharma \\ ${ }^{1}$ Department of Zoology, University of Jammu, Jammu-180006 \\ ${ }^{2}$ School of Biotechnology, University of Jammu, Jammu-180006
}

\begin{abstract}
Datte-Da-Talab, a subtropical temple pond of Jammu region is situated near Birpur at $32^{\circ} 39^{\prime} 50^{\prime \prime} \mathrm{N}$ and $74^{\circ} 57^{\prime} 10^{\prime \prime} E$ just $17 \mathrm{kms}$ from Jammu city. This pond is extensively used by number of pilgrims for drinking, bathing and various religious activities. The study was carried to analyse water for physico-chemical status for a period of one year (May, 2011 to April, 2012) and along with Bacteriological analysis. A total of sixty seven isolates were obtained by using streak plate method and further studied by Gram's staining technique. Among the isolated bacteria 18 were further studied for biochemical analysis and the result revealed the presence of Staphylococcus sp., Streptococcus sp., Shigella sp., Escherichia sp., Enterobacter sp., Salmonella sp., Pseudomonas sp. and Bacillus sp. Comparison of bacterial count results, showed that the sediments are more productive source of micro-organisms and contains higher quantity of bacteria than pond water. A good number of bacterial count and the presence of Escherichia, Enterobacter, Pseudomonas indicate significant level of microbial pollution of the pond. During the study period it was found that average value of physical and chemical parameters of pond water and that of sediments support the bacterial growth and flourishment. So, the present research work provided a baseline data to generate better restoration and conservation programme as this pond has lot of religious and therapeutic importance.
\end{abstract}

Keywords: Bacteriological, Bacterial count, Gram's staining technique, Streak plate method.

\section{Introduction}

Pond "Datte Da Talab" is one of the important subtropical perennial temple pond of Jammu region. It has always been a spot of religious activities by people which involves bathing and drinking, addition of flowers, oil, ghee, earthen vessels, rice, cereals, clothes etc. which have affected the water quality resulting in increased anthropogenic pressure. Accumulation of variety of inorganic and organic pollutants which are high in organic matter and essential nutrients brings about changes in the microflora [1]. Bacteria play an important role in global ecosystems which are being important factors in controlling the quality of water and are fate determinators of environmental pollution [2]. They also act as important component of microbial communities and play an important role in nutrient and carbon cycling [3,4]. Assessment of water quality requires examination of both bacteriological and physico-chemical parameters. It is more significant to conform the standards of microbiological water quality along with physico-chemical characteristics of water for assessing the quality of water [5]. Good quality of water is odourless, colourless, tasteless, free from organic and faecal contamination and physico-chemical characteristics are always present within the optimum limits. Bacteriological assessment of water is a powerful and important tool to study the water quality and status of hazardous microorganisms. The present investigation enabled a comprehensive and systemic analysis of the monthly physico-chemical fluctuations along with bacterial status including the pollution indicator bacteria of this temple pond.

\section{II.1 Location and Site Description}

\section{Material And Method}

Pond Datte da Talab is a sub-tropical, beautiful and rural temple pond, named after great godman of Jammu Datta Ranpat Devji. This holy temple pond is very famous for its religious and therapeutic importance. The pond is rectangular with concrete stairs along the circumference. The temple pond is situated in the district Samba of Jammu division and is located at $32^{\circ} 39^{\prime} 50^{\prime \prime} \mathrm{N}$ and $74^{\circ} 57^{\prime} 10^{\prime \prime} \mathrm{E}$ at an average elevation of 423 meters above msl. Four sites were selected for the present study at four different sides of the rectangular pond. (Fig. a)

\section{II.2 Collection of samples and isolation of Bacteria \\ II.2.1 Bacteria}

For bacterial analysis of water and sediments, water sample was collected in autoclaved glass bottles and sediment sample was collected in petriplate with the help of sieve. 
Water samples and sediment samples were serially diluted upto $10^{-4}$ dilution and $0.1 \mathrm{ml}$ of each dilution were inoculated in nutrient agar media by spread plate method. After inoculation all plates were incubated at $37^{\circ} \mathrm{C}$ in the incubator for 48 hours. Then after different bacterial colonies were seen on the petri plates. The bacterial colonies were counted for Colony Forming Unit (C.F.U). A total of 67 pure cultures were isolated using rapid qualitative streak plate method. Morphology of these sixty seven cultures was studied by gram staining technique. Out of these cultures eighteen cultures (twelve sediment culture and six water culture) were selected for different biochemical analysis. Bacterial colonies were isolated following Cappuccino and Sherman [6].

\section{II.2.2 Physico-chemical parameters}

For studying physico-chemical parameters of water, monthly sampling was done from May, 2011 to April, 2012. Water samples were collected in plastic water samplers of two litre capacity. Measurement of parameters like air temperature, water temperature, $\mathrm{pH}, \mathrm{FCO}_{2} / \mathrm{HCO}_{3}{ }^{-}$, $\mathrm{DO}$ and $\mathrm{CO}_{3}{ }^{2-}$ was done on the spot and rest were determined within two hours of water sample collection in the laboratory following standard methodology of Adoni and A.P.H.A. [7, 8].

For analysis of chemical parameters of sediments from which bacteria were isolated, sample was collected using sieve. The $\mathrm{pH}$ of sediment was determined by using $\mathrm{pH}$ meter (Hanna, model HI, 98130), Carbonates and Bicarbonates were determined using Indian Standard Method \& (A.P.H.A. [8], Argentometric method using Potassium chromate as indicator was used for the determination of chlorides in sediments [9], Calcium and Magnesium in the sediment was estimated by the EDTA-titrimetric method [9], Organic carbon \& Organic matter were calculated using method of Walklay and black [10] and Total nitrogen was calculated using Kjeldahl's Method [11].

\section{II.3 Identification of Bacteria}

In order to identify bacteria, different methods which were used are Cultural characteristics, Morphology and Staining reaction, Biochemical reaction. The cultural characteristics such as colour and surface of colonies were observed along with any other peculiar feature of culture growth on agar plates. Morphology of these sixty seven cultures was studied by gram staining technique. Bacterial colonies were isolated on the basis of different biochemical test viz, Starch hydrolysis, Lipid hydrolysis, Casein hydrolysis, Gelatin hydrolysis, Triple sugar-iron agar, $\mathrm{H}_{2} \mathrm{~S}$ production, Citrate utilization test, Catalase test, Urease test, Indole Production test. Morphological and biochemical tests were done for the identification of particular bacteria as per methods given by Cappuccino and Sherman and Bergey's Manual $9^{\text {th }}$ edition $[6,12]$.

\section{III.1 Isolated Bacteria}

\section{Result And Discussions}

During the study period, a total of 67 isolates were obtained for pure culture and Gram's staining results revealed that out of 18 isolates of water, three were Gram-positive cocci and 10 were Gram-negative cocci while two were Gram-positive rods and three were Gram-negative rods. Similarly, out of 49 isolates of sediment 23 were Gram-positive cocci and 18 were Gram-negative cocci while 5 were Gram-positive rods and three were Gram-negative rods (Table 3). Similar studies by using Gram's staining technique were used by various workers for studying different Gram-positive and Gram-negative bacteria [13, 14, 15].

18 isolates (12 from sediment and 6 from water) were further studied for biochemical analysis (Table 1 \& 2). Out of 18 bacterial isolates, 14 were identified as Gram-negative and 4 were Gram-positive. Among four gram-positive isolates two were rods and remaining two were cocci. Gram-positive rods were identified as Bacillus sp. whereas Gram-positive cocci were identified as Staphylococcus sp. and Streptococcus sp. Among 14 gram-negative isolates eight were cocci and remaining six were rods. Gram-negative cocci were identified as Shigella sp. and rest five were unidentified coccus species. Gram-negative rods were identified as Escherichia sp., Enterobacter sp., Salmonella sp., Pseudomonas sp. and Bacillus sp. A list of 8 identified bacteria given in the table $4 .[16,17,18,19,20]$

\section{III.2 Bacterial Count}

During the study period, bacterial count in dilution $10^{-1}$ being $1.35 \times 10^{4} \mathrm{CFU} / \mathrm{ml}$ in water sample and too numerous to count (TNTC) in sediment sample, the number decreases further with dilution $10^{-2}$ to $10^{-4}$ (Table $5 \& 6$ ). The results revealed that the sediment is much more dynamic source of microorganisms and contains higher quantity of bacteria than pond water. The present observation is in complete conformity with the findings of Jun et al. and Burh [21,22] who concluded that the soil is a much more productive source of microorganisms than is water.

A good number of colony counts and the presence of Escherichia sp., Bacillus sp., Enterobacter sp., Streptococcus sp. and Staphylococcus sp. clearly indicated significant level of microbial pollution of water 
body. Presence of Escherichia coli is this study indicated possible faecal contamination. In India, Patra et al. showed positive relationships between faecal indicators and pathogenic microorganisms. Pseudomonas sp. acts as an indicator of organic pollution [23]. The pond "Datte da Talab" is being used for bathing and religious activities by number of people and which is likely to be infected with these types of water borne pathogens and this may also cause too many gastrointestinal diseases like diarrhoea, dysentery, typhoid etc.

\section{II.3 Isolated bacteria and its relationship with physico-chemical parameters}

The relationship between bacteria and the physico-chemical environment of water and sediments are of great significance and has received the attention of researchers [24, 25]. As compared to water, sediment contains large number of bacteria because compounds like starch, casein, urea, and lipid reach the bottom sediments before being decomposed in the water.

In the present investigative study of subtropical pond "Datte da Talab" all physico-chemical parameters of sediments showed significant relationship with bacterial count. Dark brown colour of sediments, organic carbon $(1.62 \%)$ and high organic matter $(2.79 \%)$ showed high content of organic waste in the bottom sediments. $\mathrm{pH}$ of the sediment sample showed alkaline nature (8.1) and most of the isolated bacteria grow at slightly alkaline $\mathrm{pH}$ with high organic content (Table 7). Such characteristics of bottom sediments revealed organic pollution and helped in the growth of pollution indicator bacteria such as Escherichia coli, Pseudomonas sp., Enterobacter sp. etc. which were isolated during present research studies. Other parameters such bicarbonates, calcium, magnesium and chlorides are essential ions which stimulates microbial life.

Physico-chemical parameters of water are also important along with nutrients and sediment characteristics that affect bacterial growth. The result show well fluctuating range of physico-chemical parameters as shown in the table 8. This fluctuating range of physico-chemical state of water in the pond showed an identifiable relation with some bacteria so studied. It was seen that Pseudomonas sp. showed presence at temperature ranged between 11.63 to $33^{\circ} \mathrm{C}$ in presently studied water body. This finding supports the earlier finding of Guo et al. [24]. Presence of 8 bacterial genera finds a good support from the fact that bacteria are known to exist in the range of $\mathrm{pH}$ 6.5-9.0 and this pond water showed a well limit of 7.65 to 9.4 of $\mathrm{pH}$ thus providing suitable environment for bacterial flourishment.

\section{IV.1 Figures}

\section{Figures And Tables}

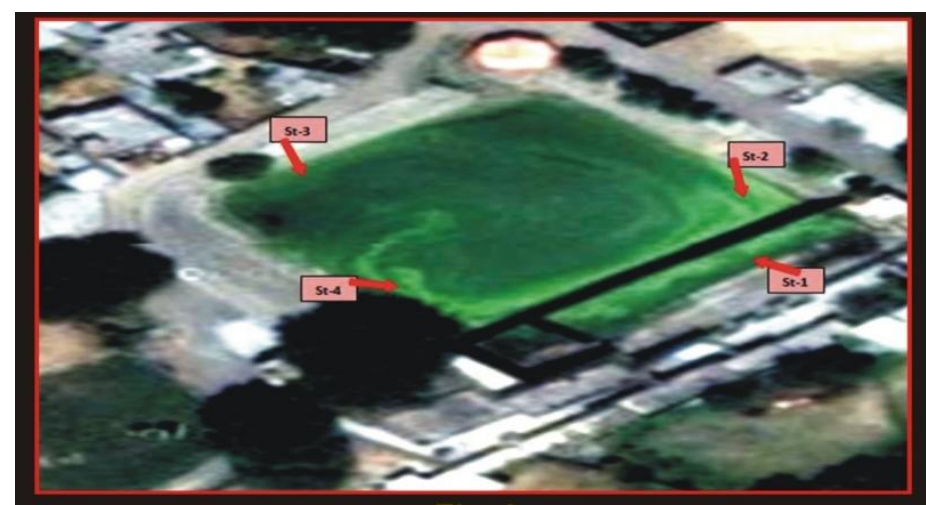

Fig. a: Satellite view of Datte da Talab Pond

\section{IV.2 Tables}

Table 1: Cultural and biochemical characteristics of bacterial isolates from water sample.

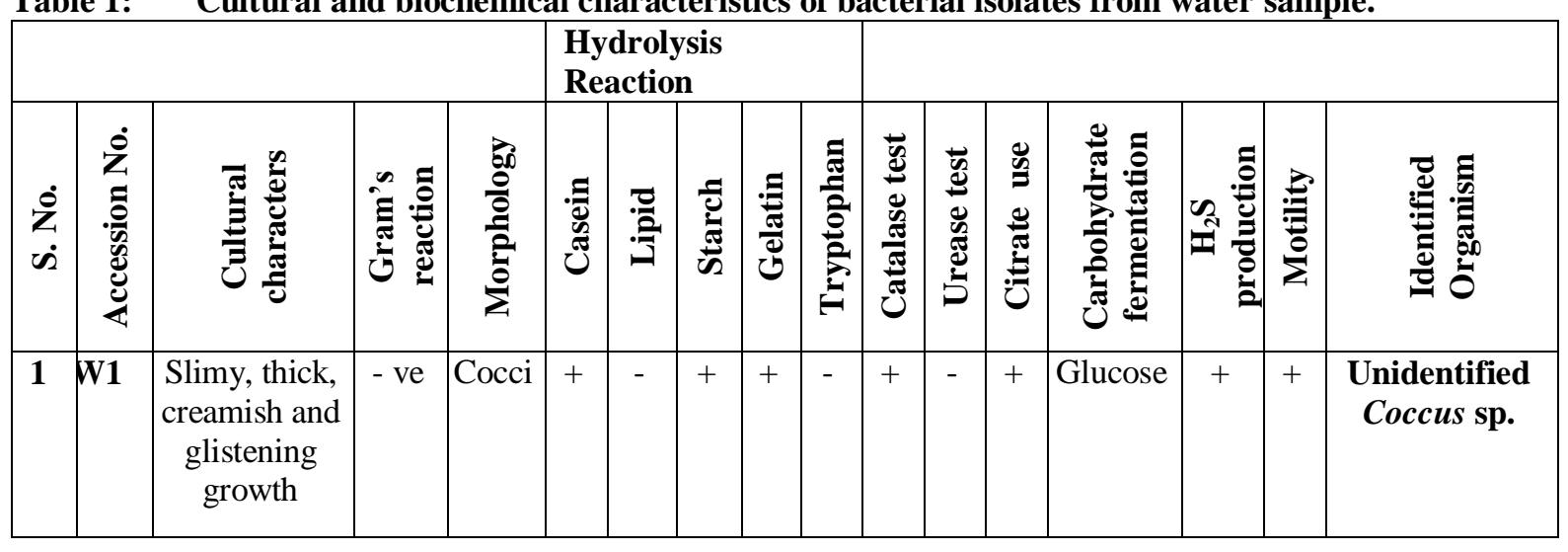


Bacteriological quality assessment of a subtropical temple pond of Birpur, Jammu (J\&K, India)

\begin{tabular}{|c|c|c|c|c|c|c|c|c|c|c|c|c|c|c|c|c|}
\hline 2 & W2 & $\begin{array}{c}\text { Thin, } \\
\text { creamish- } \\
\text { white growth }\end{array}$ & - ve & Rod & + & - & - & - & + & + & - & + & $\begin{array}{l}\text { Lactose } \\
\text { and/or } \\
\text { Sucrose }\end{array}$ & - & - & Escherichia sp. \\
\hline 3 & W3 & $\begin{array}{l}\text { Thick, slimy, } \\
\text { pinkish and } \\
\text { glistening } \\
\text { growth }\end{array}$ & - ve & Rod & + & + & + & + & - & + & - & + & Glucose & + & + & Bacillus sp. \\
\hline 4 & W4 & $\begin{array}{l}\text { Thick, slimy } \\
\text { and white } \\
\text { growth }\end{array}$ & - ve & Cocci & + & - & + & + & - & + & - & + & $\begin{array}{c}\text { Lactose } \\
\text { and/or } \\
\text { Sucrose }\end{array}$ & + & + & $\begin{array}{l}\text { Unidentified } \\
\text { Coccus sp. }\end{array}$ \\
\hline 5 & W5 & $\begin{array}{c}\text { Thin, } \\
\text { creamish- } \\
\text { white growth }\end{array}$ & - ve & Cocci & + & - & + & - & + & + & - & + & Glucose & + & + & $\begin{array}{l}\text { Unidentified } \\
\text { Coccus sp. }\end{array}$ \\
\hline 6 & W6 & $\begin{array}{c}\text { Thick, white, } \\
\text { opaque waxy } \\
\text { growth }\end{array}$ & - ve & Rod & + & - & + & + & - & + & - & + & $\begin{array}{l}\text { Lactose } \\
\text { and/or } \\
\text { Sucrose }\end{array}$ & + & - & Bacillus sp. \\
\hline
\end{tabular}

Table 2: Cultural and biochemical characteristics of bacterial isolates from sediment sample.

\begin{tabular}{|c|c|c|c|c|c|c|c|c|c|c|c|c|c|c|c|c|}
\hline \multirow{2}{*}{\begin{tabular}{l|}
\multicolumn{1}{l}{} \\
\\
$\dot{\boldsymbol{z}}$ \\
$\dot{\boldsymbol{s}}$
\end{tabular}} & \multirow[b]{2}{*}{$\begin{array}{l}\dot{0} \\
\dot{z} \\
\dot{0} \\
\dot{0} \\
\dot{0} \\
\dot{e}\end{array}$} & \multirow[b]{2}{*}{ 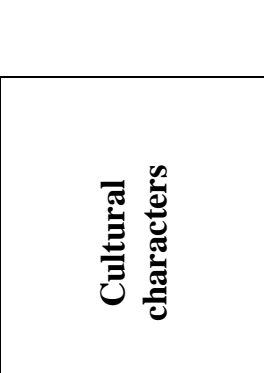 } & \multirow[b]{2}{*}{ 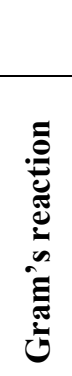 } & \multirow[b]{2}{*}{$\frac{\overrightarrow{0}}{\frac{0}{0}}$} & \multicolumn{5}{|c|}{$\begin{array}{l}\text { Hydrolysis } \\
\text { Reaction }\end{array}$} & \multirow[b]{2}{*}{ 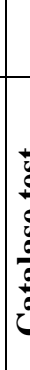 } & \multirow[b]{2}{*}{ 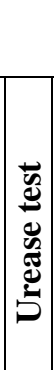 } & \multirow[b]{2}{*}{ 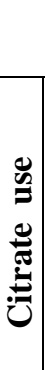 } & \multirow[b]{2}{*}{ 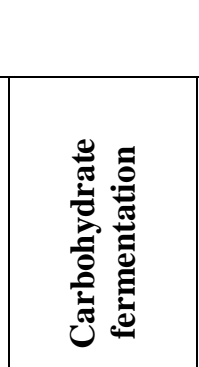 } & \multirow[b]{2}{*}{ 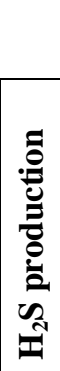 } & \multirow[b]{2}{*}{ 啻 } & \multirow[b]{2}{*}{ 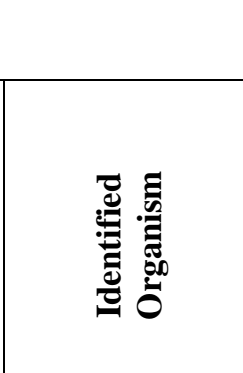 } \\
\hline & & & & & తే: & 晃 & 递 & 递 & है & & & & & & & \\
\hline 1 & S1 & $\begin{array}{l}\text { Slight greyish } \\
\text { pink, uneven } \\
\text { growth }\end{array}$ & - ve & Cocci & - & + & - & - & $\begin{array}{l}+ \\
\text { or }\end{array}$ & + & - & - & \begin{tabular}{|c|} 
No \\
fermentation
\end{tabular} & - & - & Shigella sp. \\
\hline 2 & $\mathbf{S 2}$ & $\begin{array}{c}\text { Creamish with } \\
\text { slight pink tinge, } \\
\text { opaque and slimy } \\
\text { growth }\end{array}$ & $+\mathrm{ve}$ & Rod & - & - & + & + & - & + & - & - & $\begin{array}{l}\text { Lactose } \\
\text { and/or } \\
\text { Sucrose }\end{array}$ & - & - & $\begin{array}{l}\text { Unidentified } \\
\text { Bacillus sp. }\end{array}$ \\
\hline 3 & $\mathbf{S 3}$ & $\begin{array}{l}\text { White, slimy and } \\
\text { glistening growth }\end{array}$ & - ve & Rod & + & - & - & - & - & + & - & + & $\begin{array}{l}\text { Lactose } \\
\text { and/or } \\
\text { Sucrose }\end{array}$ & - & - & Enterobacter sp. \\
\hline 4 & S4 & $\begin{array}{l}\text { Light brown and } \\
\text { opaque growth }\end{array}$ & - ve & Cocci & - & + & + & - & - & + & - & + & Glucose & + & + & $\begin{array}{l}\text { Unidentified } \\
\text { Coccus sp. }\end{array}$ \\
\hline 5 & S5 & $\begin{array}{l}\text { Creamish, thick } \\
\text { and uneven } \\
\text { growth }\end{array}$ & - ve & Rod & + & - & - & - & - & + & - & + & Glucose & + & + & Salmonella sp. \\
\hline 6 & S6 & $\begin{array}{l}\text { Slight orange, thin } \\
\text { and slimy growth }\end{array}$ & - ve & Cocci & + & - & + & + & - & + & - & + & $\begin{array}{l}\text { Lactose } \\
\text { and/or } \\
\text { Sucrose }\end{array}$ & - & - & $\begin{array}{l}\text { Unidentified } \\
\text { Coccus } \mathrm{sp} .\end{array}$ \\
\hline 7 & S7 & $\begin{array}{l}\text { Golden-yellow, } \\
\text { slimy, thick and } \\
\text { glistening growth }\end{array}$ & $+\mathrm{ve}$ & Cocci & + & - & + & + & - & + & - & - & Glucose & - & - & $\begin{array}{c}\text { Staphylococcus } \\
\text { sp. }\end{array}$ \\
\hline 8 & S8 & $\begin{array}{c}\text { Creamish, thick } \\
\text { and waxy growth }\end{array}$ & $+\mathrm{ve}$ & Rod & + & - & + & + & - & + & - & - & Glucose & - & - & Bacillus sp. \\
\hline 9 & S9 & $\begin{array}{c}\text { Smooth, white, } \\
\text { even and glistening } \\
\text { growth }\end{array}$ & $+\mathrm{ve}$ & Cocci & - & - & - & - & - & - & - & - & - & - & - & $\begin{array}{l}\text { Streptococcus } \\
\text { sp. }\end{array}$ \\
\hline 10 & S10 & $\begin{array}{l}\text { Uneven grey and } \\
\text { white circular }\end{array}$ & - ve & Cocci & + & - & + & - & - & + & - & + & \begin{tabular}{c|} 
No \\
fermentation
\end{tabular} & - & - & $\begin{array}{c}\text { Unidentified } \\
\text { Coccus } \text { sp. }\end{array}$ \\
\hline
\end{tabular}


Bacteriological quality assessment of a subtropical temple pond of Birpur, Jammu (J\&K, India)

\begin{tabular}{|c|c|c|c|c|c|c|c|c|c|c|c|c|c|c|c|c|}
\hline & & colonies & & & & & & & & & & & & & & \\
\hline 11 & S11 & $\begin{array}{l}\text { Creamish, thin } \\
\text { and translucent } \\
\text { growth }\end{array}$ & - ve & Cocci & + & - & + & + & - & - & - & - & \begin{tabular}{|c|} 
No \\
fermentation
\end{tabular} & - & - & $\begin{array}{c}\text { Unidentified } \\
\text { Coccus sp. }\end{array}$ \\
\hline 12 & S12 & $\begin{array}{l}\text { Thin, white } \\
\text { translucent } \\
\text { growth, with } \\
\text { medium turns } \\
\text { green }\end{array}$ & - ve & Rod & + & + & - & + & - & + & - & + & \begin{tabular}{|c|} 
No \\
fermentation
\end{tabular} & - & - & $\begin{array}{c}\text { Pseudomonas } \\
\text { sp. }\end{array}$ \\
\hline
\end{tabular}

Table 3: Total number of Rods and Cocci out of total 67 isolates

\begin{tabular}{|l|c|c|}
\hline Total (67) & Cocci & \multicolumn{1}{l|}{ Rod } \\
\hline Positive & $\begin{array}{c}26 \\
(38.81 \%)\end{array}$ & $\begin{array}{c}7 \\
\end{array}$ \\
& & \\
\hline Negative & $28.45 \%)$ \\
& $(41.79 \%)$ & $(08.96 \%)$ \\
& & \\
\hline
\end{tabular}

Table 4: Identified Bacteria

\begin{tabular}{|c|l|}
\hline S.No. & \multicolumn{1}{|c|}{ Identified Bacteria } \\
\hline $\mathbf{1}$ & Staphylococcus sp. \\
\hline $\mathbf{2}$ & Streptococcus sp. \\
\hline $\mathbf{3}$ & Shigella sp. \\
\hline $\mathbf{4}$ & Escherichia sp. \\
\hline $\mathbf{5}$ & Enterobacter sp. \\
\hline $\mathbf{6}$ & Salmonella sp. \\
\hline $\mathbf{7}$ & Pseudomonas $\mathrm{sp}$. \\
\hline $\mathbf{8}$ & Bacillus sp. \\
\hline
\end{tabular}

Table 5: Bacterial count for water sample

\begin{tabular}{|l|l|l|l|c|c|}
\hline S. No. & Dilutions & Dilution factor & $\begin{array}{c}\text { Number of } \\
\text { colonies }\end{array}$ & $\begin{array}{c}\text { Inoculum size } \\
(\mathbf{m l})\end{array}$ & CFU/ml \\
\hline $\mathbf{1}$ & $10^{-1}$ & 10 & 135 & 0.1 & $1.35 \times 10^{4}$ \\
\hline $\mathbf{2}$ & $10^{-2}$ & $100\left(10^{2}\right)$ & 79 & 0.1 & $7.9 \times 10^{4}$ \\
\hline $\mathbf{3}$ & $10^{-3}$ & $1000\left(10^{3}\right)$ & 64 & 0.1 & $6.4 \times 10^{5}$ \\
\hline $\mathbf{4}$ & $10^{-4}$ & $10000\left(10^{4}\right)$ & 60 & 0.1 & $6.0 \times 10^{6}$ \\
\hline
\end{tabular}

Table 6: Bacterial count for sediment sample

\begin{tabular}{|l|l|l|l|c|c|}
\hline S. No. & Dilutions & Dilution factor & \multicolumn{1}{|c|}{$\begin{array}{c}\text { Number of } \\
\text { colonies }\end{array}$} & $\begin{array}{c}\text { Inoculum size } \\
(\mathbf{m l})\end{array}$ & CFU/ml \\
\hline $\mathbf{1}$ & $10^{-1}$ & 10 & TNTC & 0.1 & - \\
\hline $\mathbf{2}$ & $10^{-2}$ & $100\left(10^{2}\right)$ & 200 & 0.1 & $2.0 \times 10^{5}$ \\
\hline $\mathbf{3}$ & $10^{-3}$ & $1000\left(10^{3}\right)$ & 150 & 0.1 & $1.5 \times 10^{6}$ \\
\hline $\mathbf{4}$ & $10^{-4}$ & $10000\left(10^{4}\right)$ & 76 & 0.1 & $7.6 \times 10^{6}$ \\
\hline
\end{tabular}

Table 7: Physico-chemical parameters of sediment sample from which bacterial colonies were isolated.

\begin{tabular}{|l|l|l|}
\hline S.No. & \multicolumn{1}{|c|}{ Physico-chemical parameters of sediment } & \multicolumn{1}{c|}{ Results } \\
\hline $\mathbf{1}$ & Colour of the sediment & Dark brown \\
\hline $\mathbf{2}$ & Hydrogen ion concentration $(\mathrm{pH})$ & 8.1 ( Slightly alkaline) \\
\hline $\mathbf{3}$ & Percentage of organic carbon & 1.62 \\
\hline $\mathbf{4}$ & Percentage of organic matter & 2.79 \\
\hline $\mathbf{5}$ & Percentage of total nitrogen & 0.140 \\
\hline $\mathbf{6}$ & Bicarbonates $(\mathrm{mg} / \mathrm{l})$ & 85.4 \\
\hline $\mathbf{7}$ & Chlorides $(\mathrm{mg} / \mathrm{l})$ & 7.98 \\
\hline $\mathbf{8}$ & Calcium $(\mathrm{mg} / \mathrm{l})$ & 28.87 \\
\hline $\mathbf{9}$ & Magnesium $(\mathrm{mg} / \mathrm{l})$ & 25.27 \\
\hline
\end{tabular}


Table 8: Physico-chemical parameters of pond Datte-da-Talab, Jammu showing maxima and minima.

\begin{tabular}{|c|l|l|l|}
\hline S.No. & \multirow{2}{*}{$\begin{array}{c}\text { Physico-chemical } \\
\text { parameters }\end{array}$} & \multicolumn{2}{|c|}{ Average \pm SD } \\
\cline { 3 - 4 } & \multicolumn{1}{|c|}{ Maxima } & \multicolumn{1}{c|}{ Minima } \\
\hline $\mathbf{1}$ & Air temperature & $38.50 \pm 0.50$ (May) & $14.30 \pm 0.54$ (December) \\
\hline $\mathbf{2}$ & Water temperature & $33.00 \pm 1.22$ (May) & $11.63 \pm 0.65$ (December) \\
\hline $\mathbf{3}$ & pH & $9.40 \pm 0.24$ (February) & $7.65 \pm 0.21$ (November) \\
\hline $\mathbf{4}$ & Free carbon dioxide & $5.95 \pm 1.49$ (November) & $\begin{array}{l}0.0 \pm 0.0 \text { (May-October, December, } \\
\text { February and March) }\end{array}$ \\
\hline $\mathbf{5}$ & Dissolved oxygen & $11.3 \pm 0.17$ (February) & $1.18 \pm 0.23$ (July) \\
\hline $\mathbf{6}$ & Carbonates & $76.50 \pm 4.97$ (July) & $0.0 \pm 0.0$ (November) \\
\hline $\mathbf{7}$ & Bicarbonates & $426.98 \pm 17.79$ (December) & $190.63 \pm 13.21$ (March) \\
\hline $\mathbf{8}$ & Chlorides & $52.70 \pm 4.17$ (May) & $11.98 \pm 1.41$ (October) \\
\hline $\mathbf{9}$ & Calcium & $40.90 \pm 4.05$ (November) & $16.43 \pm 3.82$ (February) \\
\hline $\mathbf{1 0}$ & Magnesium & $42.28 \pm 6.39$ (October) & $16.53 \pm 1.98$ (February) \\
\hline $\mathbf{1 1}$ & Phosphates & $0.05640 \pm 0.0282$ (May) & $0.0 \pm 0.0($ September, November, \\
& & & January and February) \\
\hline $\mathbf{1 2}$ & Sulphates & $0.001831 \pm 0.000090$ (April) & $0.0 \pm 0.0$ ( September and October) \\
\hline $\mathbf{1 3}$ & Nitrates & $0.5728385 \pm 0.0000444$ (July) & $0.572503 \pm 0.0000179$ (December) \\
\hline
\end{tabular}

\section{Conclusion}

Bacterial results hint towards the pollution status of the water body. Bacterial count studies showed a higher number of bacteria present in the sediments than water. Different bacterial genera which were identified are indicators of organic and pollution. 4 genera which belongs to the family Enterobacteriaceae were Escherichia sp., Enterobacter sp., Shigella sp. and Salmonella sp. Out of these Escherichia sp., Enterobacter sp. and Salmonella sp. were gram-negative rods and Shigella sp. was gram-negative cocci. Pseudomonas sp. which is a gram negative, rod shaped coliform belongs to family Pseudomonadaceae was also recorded. Three genera belonging to the phylum Firmicutes, which were isolated are Bacillus sp., Staphylococcus sp. and Streptococcus sp. Physico-chemical and bacteriological status indicated that the Datte da Talab pond is in initial stages of eutrophication. Ingestion of these bacteria during bathing and other religious activities in the pond might cause intestinal diseases and somehow entrance of water borne pathogens in food chain around this area.

Therefore, the pond has to be preserved for its intended use, a sustainable and holistic management planning is necessary for conservation of this religious and biologically important pond.

\section{References}

[1] G. Rheinheimer, Aquatic Microbiology, 4th edn. John Wiley and Sons, ( NY, 1991, 363pp).

[2] R.M. Atlas and R. Bartha, Microbial ecology: Fundamentals and Application ( $3^{\text {rd }}$ Edition) (Redwood City, Benjamin, 1993).

[3] F.T. Azam, J.S. Fenchel, J.S. Gray, L.A. Meyer-Reil and F. Thihgstad, the ecological role of water column microbes in the sea, Mar. Ecol. Prog. Ser., 10, 1983, 257-263.

[4] S. Janina, L. Mickeniene and J. Barsiene, Bacteria in the digestive system of molluscs from Lithuanian lakes, Ekologija, 54, 2008, 271-277.

[5] American Public Health Association, APHA, Standard methods for the examination of water and wastewater (19 ${ }^{\text {th }}$ ed.) (Washington, DC, 1998).

[6] J.G. Cappuccino and N. Sherman, Microbiology: A Laboratory Manual (6 ${ }^{\text {th }}$ ed.) Pearson Education Pte. Ltd. (Singapore, 2004)

[7] A. D. Adoni, Workbook on limnology 1985.

[8] A.P.H.A., Standard method for the examination of water and waste water 14th ed., APHA, AWIWA -WPCHCF (Washington, 1995).

[9] J.S. Kanwar and S.L. Chopra, Practical agricultural chemistry S. Chand and Co. (New Delhi, 1967).

[10] A. Walkley, and I.A. Black, An examination of the Degtjareff Method for determining soil organic matter and proposed modification of the chronic acid titration method, Soil Sci., 37, 1934, 29-38.

[11] H. Barnes, Apparatus and methods of oceanography. Part I. Chemical. G. Allen and Unwin Limited, London, $341,1959$.

[12] Bergey's Manual of Determinative Bacteriology (9th ed.) The William \& Wilkins Co. Baltimore, 1994.

[13] S.N. Ibe and J.I. Okplenye, Bacteriological analysis of borehole water in Uli, Nigeria, African Journal of Applied Zoology and Environmental Biology, 7, 2005, 116-119.

[14] M. L. Saha, M.R. Khan, M. Ali and S. Hoque, Bacterial load and chemical pollution level of the river Buriganga, Dhaka, Bangladesh, Bangladesh J. Bot., 38(1), 2009, 87-91.

[15] M.L. Saha, M. Nessa, M.R. Khan, M.N. Islam and S. Hoque, Bacteriological and physico-chemical water quality of four ponds of Dhaka Meterpolis, Bangladesh J. Bot., 41(1), 2012, 55-60.

[16] B.V. Kumar, P.V. Khajure and S.V. Roopa, Aquaculture, zooplankton and bacterial diversity in three ponds of Karwar district, Karnataka, Recent Research in Science and Technology, 3(4), 2011, 39-48.

[17] P. Varatraj and S. Ayjappan, Population and distribution of heterotrophic bacterial flora in fresh water bodies of Bangalore, India, Indian J. Environ. Health, 31(2), 1989, 162-170.

[18] M.L. Saha, M.R. Khan, R. Rahman and S. Hoque, Pollution level and bacterial flora of the re-excavated Dhanmondi lake, Dhaka, Bangladesh, Bangladesh J. Bot., 31(1), 2002, 9-13.

[19] M.L. Saha, T. Bari, M.R. Khan, M.N. Islam and S. Hoque, Bacteriological and physico-chemical properties of the Gulshan lake, 
Dhaka, Bangladesh J. Bot., 40(2), 2011, 105-111.

[20] R. Abila, M. Muthangya, E. Mutuku, K. Mutati, M. Munguti and C.M Musyoka, Physico-chemical and bacteriological quality assessment of shallow wells in Kitui town, Kenya, Journal of Environmental Science and Water Resources, 1(2), 2012, 27-33.

[21] X. Jun, F. Xiuzheng and Y. Tongbing, Physico-chemical factors and bacteria in fish pond, China, J. Chinese Quarterly Acad. Fish. Sci. Naga, the ICLARM, 2000, 23pp.

[22] P.M. Burh, Microbial analysis of soil and water samples from Koel river in Rourkela, Odisha, Project report, M.Sc. Life Science, 4th semester, Department of Life Science, NIT, Rourkela, 2011.

[23] A.K. Patra, B.C. Acharya and A. Mohapatra, Occurrence and distribution of bacterial indicators and pathogens in coastal waters of Orissa, Indian J. Mar. Sc., 38(4), 2009, 474-480.

[24] X. Guo, Y. Fang, and J. Wang, The preliminary studies on the bacteria types in the fish ponds applied with four kinds of animal manure and the effect upon ecosystem and yield, J. Chin. Acad. Fish. Sci., 1(1), 1988, 18-28.

[25] Z. Zhang and Y. Tang, Pond fish culture in China, Beijing Science Publishing House, 1989, 45-47. 